\title{
Burial and Fuunerary Culture of Ancient Tamils (During 1000 B.C - 250/ 300 A.D)
}

\author{
E. Iniyan
}

\begin{abstract}
This paper is a concise account of the Burial and Funerary culture of the ancient Tamils during the period 1000 B.C.E. - 250/300 C.E. culled out from the rich data available in the Tamil Sangam literature Ettuthokai, Pattupaatu, Tholkappiyam, etc., some of which are dated to 300 B.C or earlier; and correlates the data with the archaeological finds discovered during excavations made from the last decades of the $19^{\text {th }}$ century till now. The contribution of the Tamils to the Indian prehistory and history dates back to the time of the major ancient civilization of Indus valley and its classic contemporaries like Elam, Sumerian etc. This will enthuse other scholars to proceed further in this vital field and endeavour to highlight the Tamil and Indian contribution to ancient civilization and culture.
\end{abstract}

Index Terms-Tamil civilization and culture, burial and funerary culture, tamil prehistory and archaeology, tamil sangam literature and archaeology on burial practices.

\section{INTRODUCTION}

The Tamils now numbering 7 crores (living in the southernmost state of Tamilnadu in India), have made a solid contribution to the civilization of India. Their unique contribution to the Indian Pre-history and History dates back to the time of the major human civilizations of Indus valley (2900 B.C - 1500 B.C i.e., in the current nomenclature, 2900 B.C.E - 1500 B.C.E) and its classic contemporaries like Elam, Sumerian and Egyptian. This has been revealed earlier by the remarkable insights of scholars like H.R. Hall, 1913, P.T. Srinivasa Iyengar, 1929, Sir John Marshall, 1931, Henry Heras, 1953, N. Lahovary, 1963; and recently Asko Parpola, I. Mahadevan et al have validated those insights. The finds in recent excavations at Adichanallur etc., have additional proof [1]-[8]. This paper on the Burial and Funerary Culture of Ancient Tamils during the period 1000 B.C - 250/300 A.D, i.e., in the current nomenclature 1000 B.C.E - 250/300 C.E) is based on the rich information available in this regard in the Tamil Sangam literature, Ettuthokai, Pattupaatu, Tholkappiyam, etc., some of which are dated to 300 B.C or earlier; and correlates it with the archaeological finds.

\section{LITERARY EVIDENCE (SANGAM PERIOD)}

The archaeological evidences on the burial practices of the ancient Tamils have been tied up with ancient Tamil literature only from the middle of the $19^{\text {th }}$ century; but the

Manuscript received June 25, 2014; revised August 30, 2014.

E. Iniyan was with the Department of Ancient History and Archaeology, University of Madras, Chennai, Taminadu, India (e-mail: iniyane@gmail.com). literary evidence has been available all along. It will beconvenient to summarise the broad outline of the literary evidence, before proceeding to the archaeological evidence and correlate the one with the other.

Unique among the ancient classics, Tholkappiyam, the oldest Tamil grammar (dated to circa 300 B.C or earlier) has as one of its three parts, Porulathikaram dealing with Akapporul, on the love-life of the ancient Tamils; and Purapporul on ancient Tamil polity and society. The

Porul portion 60:19-20 describes the stages in the erection of burial monuments for heroes, chiefs and kings. The stages described are:

Kaatchi: Selection of a suitable stone for the memorial by the local community.

Kaalkol: Offering flowers and hallowing the stone on which the hero's name and achievements will be inscribed.

Neerpadai: Cleaning and washing the stone.

Nadukal: Engraving the hero's relief on the stone, (frequently inscribing a few lines on his heroic action), and planting the stone at an appropriate location.

Perumpadai: Imparting the status of an idol to the stone by making offerings.

The above activities are more or less similar to the stages in the procedure prescribed in the Akamas which were later evolved for the consecration of idols for various gods in Hindu temples. (P.T Srinivasa Iyengar, Ka. Subramania Pillai and others have established that the Akamas took shape only in Tamilnadu and South India).

The Sanskrit Dharma Sastras dealing with inheritance rights also mention the mode of selecting the stone, the person authorised to perform the funerary rites (such person having claim to the property of the dead [9]. In contemporary practice, in certain instances after a woman was cremated stones are planted at two places - one at the bank of river/lake and other at the entrance to the house of the deceased. In both places, three small pebbles are tied by darbha grass and planted. For ten days the sons, descendants and relatives offer water and sesame seeds to the stones planted at the river bank [10].

Brief summary of the rich evidence contained in hundreds of individual poems included in the Sangam classics (among the Ettuthokai classics Purananuru, Pathirrupathu, Akananuru, Narrinai, Kurunthokai, Ainkurunru, and Kalithokai; and among the ten long idylls - Pattupaattu, Mathuraikanchi, Pattinappalai); as well as some evidences from later literary works also for the continuity of these practices in later centuries also:

Tamilnadu possesses numerous burial monuments scattered all over the State comprising all the traditional regions kurunchi, mullai, marutham, neithal and paala $\mathrm{i}$ 
regions. Theses monuments consist of dolmens, cist burials, cairn circles, menhirs etc. In some instances Urn burials with sarcophagus interment are found. Kurinchi and Mullai regions comprised of hill and forest regions which were favorable for the construction of the burial monuments like cairn circle (Fig. 1), dolmens (Fig. 2), dolmenoid cist all requiring rocks for the erection of burials. Cairn circle, stone circles, barrow and cairn circle entombing cist are also found in the slopes of mountains and in plain areas (probably by transporting the broken rocks from the nearby by hills). Urn burials (Fig. 3) are identified mainly in the Marutham and Neithal regions which comprises of agricultural land and sea bounded areas. Urns are considered as the oldest forms of burials as the ancient settlements were in river - fed areas which pioneered in the erecting memorials for the dead. The burial grounds are generally called as Kaadu, Purankaadu [cairn packing and cairn circles]. The term Muthukaadu in Sangam works signifies that though the people die and society is destroyed, only the burials will remain as permanent memorial. My Ph.D thesis "Archaeology of Tiruvannamalai District - From the Prehistory upto Early History" (2012) mentions specifically the relevant references to the particular poems (including the lines) relied upon in this presentation - like Purananuru (3:21, referring to 'pathukkai' or cist burial; 228:1 and 10-15; 238:1 and 256:1-7; 221:13; 223:3; 232:3 all referring herostones); Pathirupathu (44:22-23), Narrinai (271:11-12), Akananuru (109:7-8 and 157:5, both referring to cist burials. These references are not reproduced in this brief paper submitted before a wider audience which may not be acquainted with Tamil. Though the generally accepted dating of most of the individual poems of the Ettuthokai anthologies, is circa 300 B.C, perspicuous scholars considered that some individual poems may reflect the situation which obtained many centuries ago - even a millennia earlier.

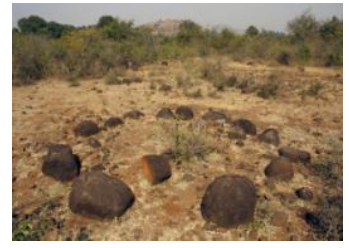

Fig. 1. Cairn circle Veeranam, Thiruvannamalai dist.

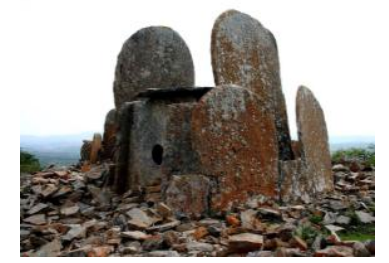

Fig. 2. Dolmen Dharmapuri district (north Tamilnadu)

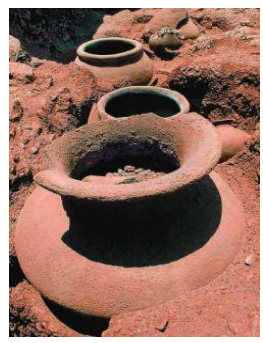

Fig. 3. Urn burial Adhichanallur, Tirunelveli district
The Sarcophagus (a legged tub - like burial custom seen interment - Fig. 4) is also seen among some of the burial monuments. The legs of this monument vary from 4 to 32 . Megalithic cultural assemblages like iron implements, black and red ware, bone pieces and other related sources were noticed inside these monuments. The size of the pits or burials were they are inserted varies on the basis of the size and shape of the sarcophagus. The size of the structure varies depending upon the size of the deceased (child to adults). Few cases had capstones which are plain and sometimes had animal (Fig. 5) and bird symbols. This interment custom is mostly seen in the burial monuments of northern districts of Tamilnadu.

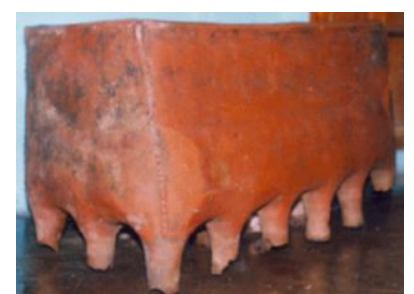

Fig. 4. Legged sarcophagus, Poondi, Thiruvallur district, northernmost Tamilnadu.

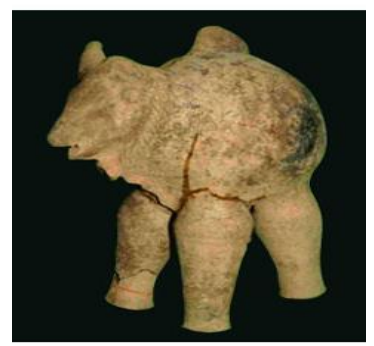

Fig. 5. Bull shaped sarcophagus, Andipatti, Tiruvannamalai district, northwestern Tamilnadu.

\section{LitERARY EVIDENCE (PosT - SANGAM)}

Among the references to the continuance during the post Sangam centuries of the funerary and burial practices of the Sangam period are the following:

Manimekalai ( $5^{\text {th }}$ century A.D), the famous Buddhist epic refers in chapter 6 (66-67) to the various kinds of burials na mely cremation (cuțuvōr), post excarnation burial (ițuvōr), burying the deceased in a pit (toțkulip pațuvōr), rock cham ber or cist burial (tālvāyin a taippōr), urn burial encapped wi th lid (täliyirkavippōr). Even in the Sangam age (when king ship and a well ordained society had emerged) the above mo des of burials survived. [This practice might even have influ enced the construction of temples, employing the stones ava ilable locally or nearby regions.]

Thevaram (7731), of the $7^{\text {th }}$ century refers to a burial grou nd as Muthukadu, which occurs in Purananuru (356:4) and signifies that though the people die and society is destroyed only the burials will remain as permanent memorial.

\section{EVIDENCE ON TAMIL BURIAL AND FUnERARY CULTURE FROM ARCHAEOLOGICAL EXCAVATIONS}

There is now a vast accumulation of evidences from numerous archaeological excavations conducted throughout 
Tamilnadu from the late $19^{\text {th }}$ century onwards on Tamil burial and funerary practices. That evidence confirms remarkably most aspects of the literary evidences discussed above.

The renowned archaeologist Dr. K. Rajan [11] has done extensive surveys in recent years in most districts and has identified nearly 2000 sites with Megalithic assemblages synchronizing with the Sangam age. Explorations alone could not reveal the various aspects of Megalithic culture, but we are able to analyze the stages of development in human settlement from nomadic life to the domestication stage and finally to the stage of cultivation of crops, (which in turn led to the economic uplift of the society). Those excavations have been conducted in the burial monuments and also in habitated areas. The correlated study and interpretation made with the materials unearthed from the burial monuments and in the habitation debris reveal that the settlements were located near the burial grounds. Apart from this, identification of remains of various crops proves that the people earned their economic source through agriculture; and their presence nearer the water source shows that the people had progressed from rain - fed cultivation to sourcing of water from ponds, lakes and rivers. Such activities would have enabled the then Tamil society to advance in civilization.

Some of the excavated places are Adhichanallur, Sanur, Mottur, Sitthannavasal, Kodumanal, Andipatti, Perumbair, Amirthamangalam and Korkai [12]-[20]. Adhichanallur yielded numerous number of Urn burials (Fig. 6) with varied megalithic assemblages like iron implements, gold objects, different types of potteries like black and red ware, black and red ware urn (Fig. 7), graffiti marks, skeletal remains and various other related materials. More than 100 acres of land at Adhichanallur are covered by burial monuments. Numerous urns have also been unearthed.

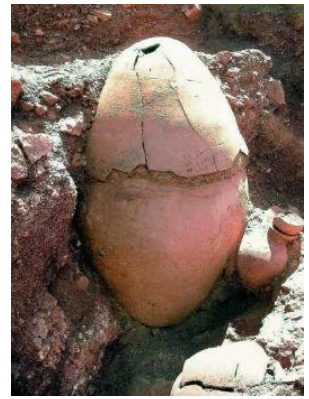

Fig. 6. Urn burial Adhichanallur.

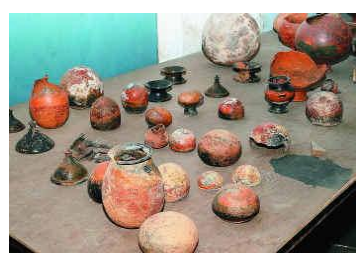

Fig. 7. Various types of potteries Adhichanallur.

The worship of burial monuments by ancient Tamils shows their belief in rebirth. For instance, at Mottur in Chengam taluk of Thiruvannamalai district, a huge anthropomorphic figure (Fig. 8) first identified by B. Narasimaiah. This figure was erected as a part of a cairn circle. It was probably a primitive form of idol worship, paving the way for constructing structural monuments of bricks and stones. The presence of both cairn circle and anthropomorphic figure at one place shows the gradual and steady development in constructional activities and changes in cultural status.

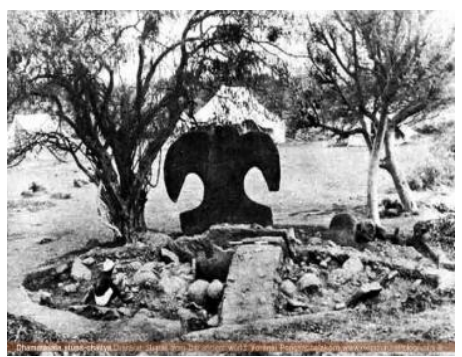

Fig. 8. 1st anthropomorphic figurine, Mottur, Tiruvannamalai district.

Sitthannavasal (Sittannavayil - the abode of great saints) in Pudukottai district famous for its paintings (Fig. 11), (which is considered as the second important site in India after the Ajanta paintings) and rock cut cave architecture have also yielded megalithic assemblages like stone circles, cairn circles (Fig. 10), dolmenoid cist (Fig. 9), urn, cist burials iron implements, black and red ware, red ware etc. Some interesting sites are described below:

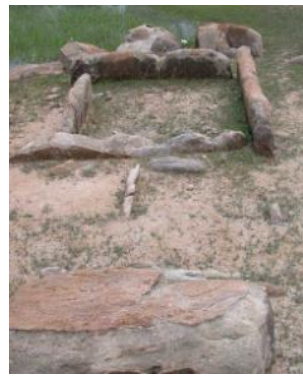

Fig. 9. Dolmenoid cist Sitthannavasal.

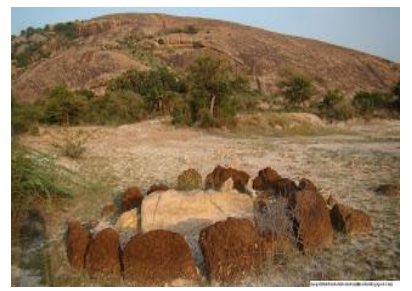

Fig. 10. Cairn circle.

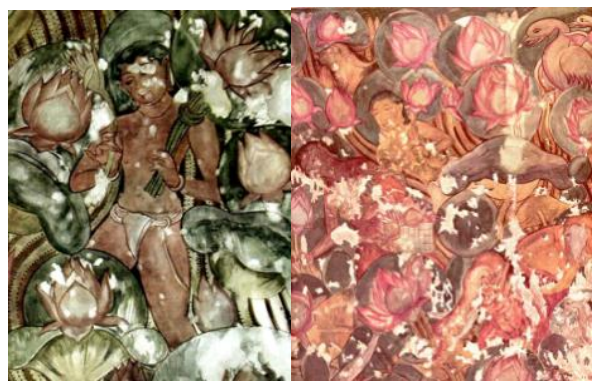

Fig. 11. Sitthannavasal paintings.

Kodumanal (Kodumanam in Sangam literature) situated in Erode district has yielded vast materials on the various dimensions of ancient Tamil society. The materials are of various types like cairn circle with cist, urn, transcepted cist 
(Fig. 12), menhir (Fig. 13), iron, copper, gold and silver objects, and potsherd with inscription (Fig. 14), terracotta figurines like god and goddess, animals and birds, beads made out semi precious stones.

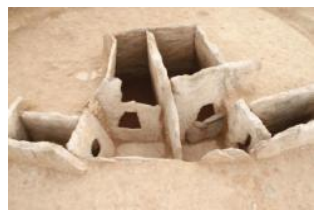

Fig. 12. Transcepted cist.

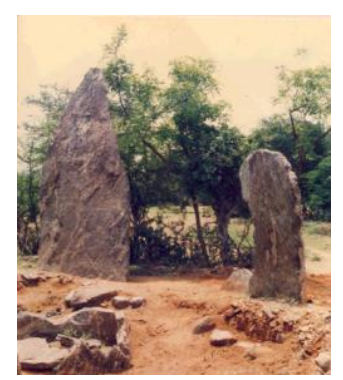

Fig. 13. Menhir, Kodumanal.

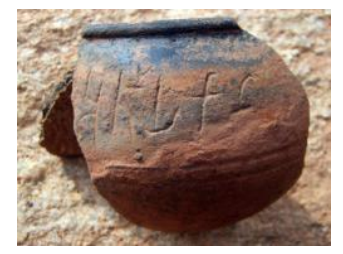

Fig. 14. Potsherd with inscription.

The Nilgiris district [21] has revealed many varieties of burial monuments like dolmen (Fig. 13), dolmenoid cist etc., described in Sangam literary works. The excavations in other districts of Tamilnadu have also revealed valuable information on burial and funerary practices.

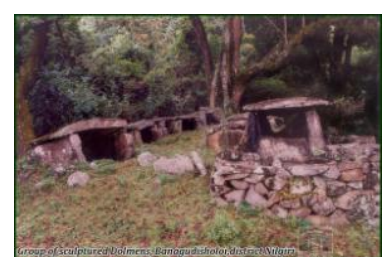

Fig. 15. Dolmens-Nilgiris burial.

\section{CONCLUSION}

A careful analysis of the literary sources gives us a full picture of the evolution, steady development and later changes in the construction of burial monuments from the beginning. The later changes were no doubt gradual and were due to the inevitable cultural, social and economical changes over the years in the Tamil society. Further enlightenment in this field (Burial and Funerary culture) depends on deeper analysis of literary sources, field surveys based on previous studies, systematic and scientific excavations, study where necessary in comparison with other sites in South India of the materials unearthed with the other disciplines like Anthropology, Geology, etc,.

\section{REFERENCES}

[1] H. R. Hall, The Ancient History of the Near East, UK, London, Methuen, 1913, Revised 1927.

[2] P. T. S. Iyengar, History of the Tamils from the Earliest Times to 600 A.D, Madras, 1929.

[3] J. Marshall, Mohenjodaro and the Indus Civilisation, Chapters XXII \& XXIII, London, vol. II, 1931.

[4] H. Heras, "The dravidians of iran, INDICA," The IHRI Silver Jubilee Commemoration, 1953, pp. 166-169.

[5] N. Lahovary, Dravidian Origins and the West: Orient Longmans, Madras, 1963.

[6] A. Parpola, Corpus of Indus Seals and Inscriptions, vol. I, Collections in India, Helsinki, 1987, Corpus of Indus Seals and Inscriptions, vol. II, Collections in Pakistan, Helsinki, 1991, Deciphering the Indus script, Cambridge University, Press, London, 1994.

[7] I. Mahadevan, "Dravidian parallels in proto-Indian script," Journal of Tamil Studies III 2-3, 1970, The Indus Scripts Texts; Concordance and Tables, Archaeological Survey of India, New Delhi, 1977.

[8] Indian Archaeology, A Review for the years from 1954-1955 to 1990-1991.

[9] K. Rajan, Tholliayal Nokkil Sangakaalam, International Institute of Tamil Studies, Chennai, 2005.

[10] R. Nagasamy. Dolmens. [Online]. Available: http://www.tamilnation.org

[11] K. Rajan, V. P. Y. Kumar, and S. Selvakumar, Catalogue of Archaeological Sites in Tamil Nadu, Heritage India Trust, Thanjavur, vol. I-II, 2009.

[12] A. Rea, Adhichanallur Excavations, Annual Report of the Archaeological Department, Southern circle Madras and Coorg, 1902-03, Madras.

[13] Indian Archaeology - A Review, pp. 66, 1990-1991.

[14] Indian Archaeology - A Review, pp. 21, 1978-1979 and B. Narasimhaiah, Neolithic and Megalithic cultures in Tamilnadu, p. 133, 1980.

[15] Indian Archaeology - A Review, pp. 39-42, 1975-1976.

[16] Indian Archaeology - A Review, p. 78, 1960-1961, Ibid, pp. 100-101, 1996-1997 and Ibid, pp. 154-155, 1997-1998.

[17] T. S. Sridar, Thamizhaga Agalaaivugal-Andipatti (2004-2005), Department of Archaeology, Govt. of Tamilnadu, Chennai, 2005.

[18] B. K. Gururaja Rao, Megalithic Culture in South India, Prasaranga, University of Mysore, 1972, pp. 121-122,

[19] Indian Archaeology - A Review, pp. 79, 1988-1989, Ancient India, pp 21-34 and Indian Archaeology - A Review, pp. 20-22, July 1954-1955.

[20] R. Caldwell, Explorations at Korkai and Kayal, Indian Antiquary, vol. 6, pp. 80-83 and Indian Archaeology - A Review, pp. 32, 1968-1969.

[21] J. W. Breeks, An Account of the Primitive Tribes and Monuments of the Nilgiris, Cultural Publishing House, Delhi, 1873, (reprint 1983) and S. Venkatachalam, "Archaeology of Moyyar river valley," M. Phil dissertation, Tamil University, Thanjavur, 2004.

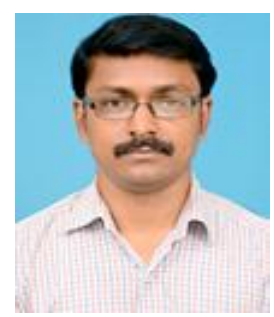

E. Iniyan was born at Thanjavur, Tamilnadu, India on July 8, 1980. He completed his B.A in history at Loyola College, Chennai, Tamilnadu, India in 2003. And He did his M.A. in ancient history and archaeology at University of Madras, Chennai, in 2005. He was awarded Ph.D. degree for his research in the topic "Archaeology of Tiruvannamalai District (From the Earliest upto the Early Historical period)" by University of Madras, in 2012. He has for some time worked as a guest lecturer in the said Department of Ancient History and Archaeology from 2013-April 2014. He has also worked as a documentation officer in 2011 - 2012 on the project "National Mission on Monuments and Antiquity", sponsored by archaeological survey of India, New Delhi, India. He was awarded junior research fellowship by Central Institute of Indian languages, Mysore, Karnataka, in 2007-2009. He is a member of learned societies like Indian History Congress, South Indian History Congress, Tamilnadu History Congress and The Tamilnadu Archaeological Society, Thanjavur. He has taken part in excavations at Palur (Chengalppatu district), Melchitthamur (Villupuram district), Arpakkam (Kancheepuram district). He has himself surveyed archaeological remains in about 1000 sites, as part of his $\mathrm{Ph} . \mathrm{D}$ research work in Thiruvannamalai district, Tamilnadu. 